\title{
EFL Learners' Use of Self-Regulated Learning Strategies and Impediments they Face When Learning Writing Skills: A Self-Hand Feeding Approach
}

\author{
Mesele Ayalew Fentaye (M.Ed in TEFL) \\ Department of English Language and Literature, Adigrat University, P.O.Box.50, Adigrat, Tigray, Ethiopia
}

\begin{abstract}
The purposes of this study were to identify the self-regulated learning strategies students use when learning writing skills, to find out the hindering factors students face to practice self-regulated learning strategies and to explore the strategies used by writing skills instructors to encourage their students' use of self-regulated learning strategy. The students self regulated learning strategies questionnaire and writing skills instructors' semi-structured interviews were the instruments to collect the data. The questionnaire that was adapted from Barnard, Lan, To, paton, \& Lai, (2009) was designed based on the review of the related literature and it consisted of 27 closed-ended items arranged thematically as time management, self evaluation, attention control, self motivation and help seeking and 2 open-ended items (concerning the challenges that students face when learning writing skills courses and about what specific strategies they need from their writing skills instructors to help them effective self regulative learner). The participants of the study were selected using available and purposive sampling technique. The data collected from the participants using self-regulated learning strategies questionnaire were analyzed via percentage, and the result showed that students are good at using time management (but deficient in using their non-lecture time \& their arranged plan), self motivation (though they showed resistance not to work on more writing practice tasks), social support, and attention control strategies (in some extent) but in meta-cognitive/self evaluation strategies, they were not found good. The result also showed that lack of awareness among students on what strategy to choose and how to use it, lack of interest among students to work cooperatively with mates, lack of more concentrated practice on writing tasks, learners' resistance to more writing tasks given by their teachers, teacher dominated corrective feedback provision to every activity, and lack of sufficient time to teach what strategy students need to use are some of hindering factors. The courses' instructors were also found using explicit corrective feedback, and explicitly explaining strategies called direct instruction, and student centered instructions like group work. Finally, this study had suggested writing skills instructors and EFL students that they should use more strategies like guided and independent practice, should minimize an explicit corrective feedback that means use progress feedback, and use reflective practices. In addition, further research into the EFL students' use of self regulated learning strategies against different variables is also recommended.
\end{abstract}

Keywords: English as a Foreign Language, Self-Regulated, Impediments, Strategies

\section{Introduction}

\subsection{Background and Statement of the problem}

The world nowadays, is in need of human capital that is more competitive since competitive individual is known to be innovative, creative, proactive, motivated, highly skilled, flexible, available, and most important to have complex and critical thinking, and these traits of human capital can be shaped by the practice of learner autonomy. So language learning process works through learners' own reflection on how they learn and it makes learners active in the sense that they learn to analyze their learning strategies (Asmar, 2013 \& Rivas, 2013as cited in Elizabeth, Tadlock \& Zumbrunn (2011).

One of the manifestations of student-centered pedagogy has been the notion of students' autonomy which can be interpreted as students' self-initiation and self-regulation; language learners in the language learning are now expected to carry responsibility for their own learning and to do their own share (Benson, 2011, as cited in Farahani, 2014). According to Zimmerman (2008, P.167), "self-regulated learning is the degree to which students are metacognitively, motivationally and behaviorally active participants in their own learning process". This means that self-regulated learners choose the suitable learning strategies consistent with the feedback they receive regarding the effectiveness their academic performance and/or their skills, or learners will be motivated when they realize that they hold the responsibility for their language learning.

In the traditional school setting, in teacher-centered approach, learners tend to depend on their teachers for the acquisition of information. They expect their teachers to provide learning material, to motivate them, and to take responsibility for the learning process _ that means they expect their teachers to control of what is being learned, how it is learned, when it is learned, and to what extent. According to Boekaerts \& Niemivirta (2000), the generally accepted role pattern where in teachers convey declarative and procedural knowledge and students must find a way to comprehend, store, and activate that knowledge leads to a situation in which students lack sufficient opportunity to organize and regulate their own learning. Here, questions like, "are teachers well equipped to create conditions that will foster the development of effective self-regulatory skills?" can be raised. However, every class, especially at university level, is composed of a variety of learning types, but teachers, even well equipped ones, are faced with multitude of students, each of whom has different 


\section{International Journal of Science and Research (IJSR) \\ ISSN (Online): 2319-7064}

Index Copernicus Value (2015): 78.96 | Impact Factor (2015): 6.391

preferences for how to experience learning materials. So, how then are teachers supposed to create a lesson that meets the preference (needs) of all students when they are teaching? Therefore, to overcome such challenges, Adigrat University is highly dedicated to encourage its students' independent learning habit, which is associated with autonomous (self-regulated) learning through different mechanisms like networking. According to Jarvela(2011) and Zimmerman (2000) as well as Harris, Friedlander, Sadler, Frisselle \& Graham (2005), self-regulated learning has many advantages for all students in general and EFL writing learning in particular: it helps students create better learning habits and strengthen their study skills, and it also helps them to monitor their performance to evaluate their academic progress since there is the concept of internal feedback in it.

In addition to these, Meyer, Haywood, Sachdev \& Faraday (2008) state the following advantages that students can be benefited from self-regulated learning: it increases students' motivation \& confidence in their personal learning, it has grater students' awareness of their limitations and abilities to manage their learning, and enables them to plan and set goals for their learning; it also develops students to feel like they belong to the academic program and self-regulated learning enables even teachers to provide their students with different academic tasks.

Therefore, because self-regulated learning has these and other advantages for students in EFL learning, the researcher found that assessing students' use of self regulated learning strategies and identifying the hindering factors that they face during their Intermediate writing skills learning is a sound issue of research.

\subsection{Research Questions}

To accomplish the study, the following research questions were formulated.

1) What self -regulated learning strategies do students use in learning writing skills?

2) What are the challenges that students face to use selfregulated learning strategies?

3) What are the roles of writing skills teachers in encouraging students' use of self-regulated learning strategies?

\subsection{Objectives of the study}

This study is aimed to achieve the following objections.

1) To assess the self-regulated learning strategies EFL students use in learning writing skills

2) To find out the hindering factors that students face to use self -regulated learning strategies

3) To explore the strategies used by writing skills teachers to encourage their students use of self-regulated learning strategies

\subsection{Significances of the Study}

Learner autonomy must be a reality not merely a name or slogan. How to empower learners for true lifelong and personalized learning? This is one of the man questions that self-regulated learning strategies use concerns. Selfregulated learning strategies play a significant role in keeping a student learn English language in general and writing skills in particular easily: it makes them evaluate their own performance on the learning tasks; it enables them to formulate their own learning goals (that means they don't wait for their teachers to set them goals). More importantly, it is significant for EFL teachers not to control each and everything by themselves rather to make their students set their learning goals toward completing the task. It can also make the students approach educational tasks with confidence, diligence and resourcefulness. Furthermore, the finding will serve researchers, trainers, material designers, teachers and students as a reference document.

\subsection{Limitations of the Study}

Because of different constraints, the study was delimited to writing skills only. However, had it included other skills like listening and reading, and treated students' use of selfregulated learning strategies against their gender, academic achievement, it would have been more inclusive and completed.

\section{Methodology}

\subsection{Design and Participants}

The design of the study was descriptive: descriptive statistics (frequencies and percentages) were used to the result of the questionnaire. The study was conducted at Adigrat University, which is found at the center of eastern zone of Tigray region. In the Department of English Language and Literature, there are 92 (32 boys \& 60 girls) students. Of those 92 students, 44 (18 boys \& 26 girls) were freshmen (new entries), so they were not taken as participants of this study since they did not begin to learn writing skills courses. Therefore, the participants were 48 (14 boys and 34 girls) students as well as all instructors who taught writing skills courses.

\subsection{Sample population and Sampling Technique}

Because the researcher believed that the number of the participants were manageable, all year II and year III students (48 in number) and writing skills instructors ( 2 in number) were included as participants of the study using available and purposive sampling techniques for the students and the instructors respectively.

2.3. Instruments of Data Collection: Two basic instruments were used to collect the necessary data.

\section{Questionnaire}

The first instrument used in this study was the students' selfregulated learning strategies questionnaire, which was adapted from Barnard, Lan, To, paton, \& Lai, (2009). Its design was based on the review of the related literature and it consisted of 27 closed-ended items and only 2 open-ended items (concerning the challenges that students face when learning writing skills courses and about what specific strategies they need from their writing skills instructors to help them effective self regulative learner). For the closed-

\section{Volume 6 Issue 1, January 2017




\section{International Journal of Science and Research (IJSR) \\ ISSN (Online): 2319-7064}

Index Copernicus Value (2015): 78.96 | Impact Factor (2015): 6.391

ended items, a five point likert scale (in the form of adverbs of frequency): 5(I always use it), 4(I usually use it), 3(I sometimes use it), 2(I rarely use it) and $\mathbf{1}$ (I never use it) was used. The closed-ended items were also arranged thematically as follows: 1-6(time management), 7-12(self evaluation), 13-18(attention control), 19-24(self motivation) and 25-27(help seeking). The open-ended items, on the other hand, were designed in a way that students are able to list down the hindering factors (challenges) they encounter to use self-regulated learning strategies as well as to specify what strategies they need from their writing skills instructors to be more self regulated learner in learning writing skills.

\section{Interview}

The second instrument used in this study was an interview for writing skills instructors. The interview was semistructured interview and designed in the way to get the data about the level where students (in their teacher's view) are, what strategies/activities do writing skills instructors use to make their students self-regulative in learning writing skills and what do writing skills instructors consider as challenges for encouraging students use of self regulated learning strategies?

\subsection{Data Collection Procedures}

As it is described before, the total number of participants (i.e. students) was 48; however, at the time of administering the questionnaire, 5(3 from year_II and 2 from year-III) students were not available. So, after they were given orientation about the purpose of the questionnaire and how to answer, it was administered to only $\mathbf{4 3}$ students at a time when they were in class. As far as the instructors' interview is concerned, it was conducted in their office through semistructured form.

\subsection{Techniques of Data Analysis}

The data obtained from students' closed-ended questionnaire were analyzed quantitatively in the form of percentage whereas the data obtained through open-ended item of students' questionnaire and the data collected through writing skills' instructors interview were analyzed qualitatively.

\section{Result and Discussion}

This session presents and discusses the results obtained both from students self-regulated learning strategies use questionnaire and from writing skills instructors semistructured interview.

\subsection{Results of the Students' Questionnaire}

Table 1: Students' response to their time management strategies

\begin{tabular}{|l|l|l|l|l|c|}
\hline \multicolumn{1}{|c|}{ Items } & \multicolumn{5}{c|}{ Frequencies (\%) } \\
\cline { 2 - 6 } & $5(\%)$ & $4(\%)$ & $3(\%)$ & $2(\%)$ & $1(\%)$ \\
\hline I have time schedule for studying & 11.63 & 23.26 & 58.14 & 6.98 & - \\
\hline I make good use of my planed time for study & - & - & 6.98 & 81.40 & 11.63 \\
\hline I allocate extra study time & 23.26 & 23.26 & 39.53 & 13.95 & - \\
\hline I complete activities on time & 27.91 & 48.84 & 18.61 & - & 4.65 \\
\hline I choose tasks appropriate to the time bearing in mind tiredness & 2.33 & 18.60 & 55.81 & 23.26 & - \\
\hline I make effective use of non lecture time & 6.98 & 25.58 & 13.95 & 62.79 & 4.65 \\
\hline
\end{tabular}

As presented in table 1, students were asked about seven items, (with always, usually, sometimes, rarely \& never use options), concerning their time management strategies use. The result shows us that nearly all $(93.36 \%$ of) respondents do not use 'time schedule/plan they arranged. They, in different extent of frequencies, allocate more time to study, but majority (67.44\%) do not use their non lecture time effectively; they seem to have failure in choosing tasks appropriate to the time bearing in their mental tiredness. Thus, according to the information presented in table 1, majority students are good at using time management strategies.

Table 2: Students' response to their self evaluation strategies

\begin{tabular}{|l|c|c|c|c|c|}
\hline \multicolumn{1}{|c|}{ Items } & \multicolumn{4}{c|}{ Frequencies (\%) } \\
\cline { 2 - 6 } & $5(\%)$ & $4(\%)$ & $3(\%)$ & $2(\%)$ & $1(\%)$ \\
\hline I self-test my own recall of important facts & 4.65 & 18.60 & 16.28 & 46.51 & 13.95 \\
\hline I ask myself a lot of questions about writing activities and the course materials & 11.63 & 51.16 & 27.91 & 9.30 & - \\
\hline I self-test my understanding by having self feedback & 23.26 & 16.80 & 30.23 & 20.93 & 6.98 \\
\hline I prepare well for a test & 88.37 & 11.63 & - & - & - \\
\hline I think carefully about my writing skills learning strategies & - & 6.98 & 34.88 & 11.63 & 46.51 \\
\hline I ask myself questions to make sure I know the writing materials I am studying & 9.30 & 18.61 & 41.86 & 23.26 & 6.98 \\
\hline
\end{tabular}

As can be seen in table 2, concerning the four items (i.e. item $8,10,12 \& 13)$, more than half of the respondents $(60.46 \%, 27.91 \%, 58.14 \% \& 30.24 \%$ respectively) replied that they do not apply self test, like provision of self feedback, self questioning as well as do not think carefully about learning strategies they should use; however, when students apply self evaluation learning strategy, they can make changes to those goals and strategies based upon learning outcomes (Zimmerman, 2004). According to Baba (2001), independent _ means self-regulated learners are characterized as they know how they can improve their progress by evaluating themselves; they have the skills of recalling important facts; they can assess their own thinking _they self test to know their weaknesses and strengths. Regarding their preparation, both for tests, $88.37 \%$ (always) and $11.63 \%$ (usually) prepare well for tests and half of

\section{Volume 6 Issue 1, January 2017 www.ijsr.net}




\section{International Journal of Science and Research (IJSR) ISSN (Online): 2319-7064 \\ Index Copernicus Value (2015): 78.96 | Impact Factor (2015): 6.391}

them, $51.16 \%$, responded that they ask themselves a lot of questions about writing activities and the course materials. This finding also supported by Stephenie \& Vic (2012) who state that self-regulated learners are good at asking themselves different questions, and are, most of the time, ready for tests and revisit materials they are given. Therefore, students in their writing skills learning need to use self evaluation strategy.

Table 3: Students' response to their attention control strategies

\begin{tabular}{|l|c|c|c|c|c|}
\hline \multicolumn{1}{|c|}{ Items } & \multicolumn{5}{c|}{ Frequencies (\%) } \\
\cline { 2 - 6 } & $5(\%)$ & $4(\%)$ & $3(\%)$ & $2(\%)$ & $1(\%)$ \\
\hline I choose the location where I study to avoid too much distraction & 30.23 & 32.56 & 30.23 & 6.98 & - \\
\hline I have trouble making up my mind about things & - & 23.26 & 18.60 & 46.51 & 11.63 \\
\hline I get easily distracted from my plans & 30.23 & 39.53 & 6.98 & 23.26 & - \\
\hline I find an attractive and practical place to study & 81.40 & 18.60 & - & - & - \\
\hline I think a lot about what and how I am going to write on & 37.21 & 55.81 & 30.23 & - & - \\
\hline When I am studying, I stop once in a while and go over what I have studied & - & 4.65 & 37.21 & 51.16 & 6.98 \\
\hline
\end{tabular}

As it is indicated above in table 3, as far as items 13, 16, and 17 are concerned, majority of the respondents $(62.79 \%$, $100 \%$ \& $93.01 \%$ respectively), taking always \& usually as positive indicators, replied that they try to choose the location where they study to avoid too much distraction, find an attractive and practical place to study, and think a lot about what and how they are going to write on. So, we can infer that majority of the students use strategies for controlling their attention to find an attractive and practical place to study. This is also supported by Winne (1995) who stated that attention controlling entails clearing the mind of distracting thoughts, as well as seeking suitable environments that are conducive to learning, for example, quiet areas without substantial noise. On other hand, about items 15 (30.23\% always, $39.53 \%$ usually \& $6.98 \%$ sometimes, totally $76.74 \%$ ) of them get easily distracted from their plans, and regarding items 14 and 18, more than half of the respondents answered that they have trouble making up their mind about things and when they study, they do not pause for a while to go over what they have studied which were seen as failure because different studies, for example, Kuhl (1985) indicates that students' academic in general and writing skills outcomes in particular increase with focused time (controlled attention) spent on-task.

Table 4: Students' response to their self motivation strategies

\begin{tabular}{|l|c|c|c|c|c|}
\hline \multicolumn{1}{|c|}{ Items } & \multicolumn{5}{|c|}{ Frequencies (\%) } \\
\cline { 2 - 6 } & $5(\%)$ & $4(\%)$ & $3(\%)$ & $2(\%)$ & $1(\%)$ \\
\hline Even when I do poorly on a test I try to learn from my mistakes & 41.86 & 23.26 & 34.88 & - & - \\
\hline I worry a great deal about tests & 95.35 & 4.65 & - & - & - \\
\hline When I take writing activities, I think about how poorly I am doing & 34.88 & 25.58 & 23.26 & 16.28 & - \\
\hline When studying writing skills, I copy notes over to help me remember materials & 9.30 & 32.56 & 39.53 & 13.95 & 4.65 \\
\hline I work on more practice writing exercises even when I do not have to & - & 6.98 & 41.86 & 41.86 & 9.30 \\
\hline Before I begin writing, I think about the points I will need to write & 90.69 & 9.30 & - & - & - \\
\hline
\end{tabular}

According to the information presented in table 4, almost all (95.35\% always \& $4.65 \%$ usually) participants showed that they worry a great deal about tests, and concerning item 21 , majority of them $(34.88 \%, 25.58 \%$ \& $23.26 \%$ always, usually and sometimes respectively) think about how poorly they are doing when they take writing activities. Thus, as far as self motivation strategies are concerned, except item 23, which is more than half of the respondents $(51.16 \%)$ do not apply it, students are self motivated without waiting for external incentive. Therefore, we can say that selfmotivation occurs when learners independently use one or more strategies to keep themselves on-track toward a learning goal. This is realized by Wolters (2003) who states that by establishing their own learning goals and finding motivation from within to make progress toward those goals, students are more likely to persist through difficult learning tasks and often find the learning process more gratifying. Zimmerman (2004) also explained the importance of self motivation as self-motivation occurs in the absence of external rewards or incentives and can therefore be a strong indicator that a learner is becoming more autonomous. Thus, students should adopt such strong habit since self motivation does have innumerable values.

Table 5: Students' response to their use of help seeking strategies

\begin{tabular}{|c|c|c|c|c|c|}
\hline \multirow[t]{2}{*}{ Items } & \multicolumn{5}{|c|}{ Frequencies $(\%)$} \\
\hline & $5(\%)$ & $4(\%)$ & $3(\%)$ & $2(\%)$ & $1(\%)$ \\
\hline I find someone who is knowledgeable in writing so I can consult with him/her I need help & 48.88 & 23.26 & 27.91 & - & - \\
\hline I share my problems of writing with my classmates & 11.63 & 34.88 & 20.93 & 25.58 & 18.60 \\
\hline I am persistent in getting help from my writing skills instructor & 72.09 & 23.26 & 4.65 & - & - \\
\hline
\end{tabular}

Based on the data presented in the above table (table 5), concerning items $25,48.88 \%$ (always), $23.26 \%$ (usually) \& $27.91 \%$ (sometimes) consult with knowledgeable person in writing they need help, and on item 27 as well majority of the respondents $(72.09 \%$ always), (23.26\% usually) are persistent in getting help from their writing skills instructors.
As it is stated by Butler (1998), it is obvious that Selfregulated learners are not expected to accomplish each and every activity by themselves, they rather can frequently seek help from others (maybe from their writing skills instructors or peers) when necessary. Thus, it can be inferred that to be self regulative learners, students should use help seeking

\section{Volume 6 Issue 1, January 2017 www.ijsr.net}




\section{International Journal of Science and Research (IJSR) \\ ISSN (Online): 2319-7064}

Index Copernicus Value (2015): 78.96 | Impact Factor (2015): 6.391

strategies. However, $44.18 \%$ of the students showed somewhat failure in sharing their problems of writing skills with their classmates. Therefore, the result of item 26 indicates us, according to Ryan, Pintrich \& Midgley (2001), teachers can promote positive help seeking habits by providing students with on-going progress feedback that they can easily understand.

In order to get additional data for the study, students were asked two open-ended questions about to list hindering factors that challenge them not to use/practice appropriate self regulated learning strategies in learning writing skills, and about the specific helps they need from their writing skills instructors to make them self-regulative learner. Regarding the first open-ended item, they, nearly all, answered that there are many challenges they face, for example, lack of awareness among themselves on what to choose and how to apply self regulated learning strategies, lack of cooperation with mates, lack of more practice on tasks even when they do not have to, and absence of good background knowledge on writing skills at high school. Concerning the second open-ended question, which was about what help they expect from their writing skills teachers, students answered that they their writing skills teachers to make them work hard by creating more opportunities for them to practice, to point out their weaknesses in writing skills such by providing answers to all their questions, to stimulate their interest in learning writing skills like by choosing appropriate activities for them to learn writing skills and so on.

\subsection{Results of instructors' semi structured interview}

As it is mentioned in chapter three, a semi-structured interview with the instructors of the writing skills course was conducted after the students' questionnaire had been completed and tabulated.

At the interview, the instructors responded to three openended questions.

Q1: How do you rate your students' use of self regulated learning strategies? Both instructors, concerning this question, reported that the students can be rated as moderate user of self regulated learning strategies, for instance, "they set goal that means they, each semester, put their expected grade for the course", "they worry much about tests", " whatever their answer is, they submit assignments on time". Though they set goal in the form of putting expected grade for the courses, "they (students) do not have short term or long term plans to achieve their goal", according to the instructors' conclusion. However, research indicates that planning and goal setting are complementary processes, as planning can help learners establish well thought out goals and strategies to be successful (Schunk, 2001). Therefore, Pressley \& Woloshyn (1995) advise us that teaching students to approach academic tasks with a plan is a viable method for promoting self-regulated learning

Q2: What strategies do you use to encourage your students to be self-regulated learner in learning writing skills?

In order to encourage students to be self-regulated learners, they (instructors) listed varieties of effective instructional strategies which they try to apply: using student-centered teaching method with group and individual tasks, providing explicit corrective feedback on writing activities/out puts, appreciating students for their try, and most of the time, according to their response, they use direct instruction. This involves, according to Zimmerman (2008), explicitly explaining different strategies to students, as well as how those strategies are used and what skills are involved in using those strategies.

Q3: What do you consider as challenges for enhancing self regulated learning in writing skills?

The interviewees explained the question as there are a number of hindering factors that could challenge them in trying to encouraging students self regulated learning in every courses. Both of them reported that students themselves are considered to be challenges_ they independently said it as: "students themselves are resistant means when I give them more writing tasks to make them expose to the skill, they complain", "since they, most of the time, complain, we always give explicit corrective feedback, write all the correct answers on their paper, for every task". But is it an acknowledged pedagogy? According to Nunan (1994) and Wood \& Millichamp (2000), if teachers do not perceive as pupils to be able to learn independently, it may restrict the opportunities for students' practice of self regulated learning strategies. So, here it can be inferred that they (the instructors) are also part of the challenges since they are doing each and every thing by their own. Other points rose by the interviewees as a challenge was shortage of time to teach and to modeling students how to use specific self regulated learning strategies and lack of sufficient resources to provide opportunities for students to learn collaboratively.

\section{Conclusion and Recommendations}

\subsection{Conclusion}

The study was aimed to find out the self -regulated learning strategies students use when learning writing skills, to assess the hindering factors students face to practice self-regulated learning strategies, and to explore the strategies used by writing skills teachers to encourage their students be selfregulated learners. Thus, based on the findings obtained through the students' self regulated learning strategies questionnaire and the writing skills instructors' interview, the following conclusions (according to the objectives) are drawn.

- Majority students have time schedule to study and are punctual in completing tasks; they set their learning goals, for instance, each semester, they put their expected grade for the course; they also worry much about tests; when they take writing activities they think about how poorly they are doing. Students also think a lot about what and how they are going to write on, and try to find an attractive and practical place to study. Nearly all students are good at using help seeking strategies. On the other hand, nearly all do not use 'time schedule/plan they arranged, and do not use their non lecture time effectively; they even seem to have failure in choosing tasks appropriate to the time bearing in mind their mental fatigue tiredness. Evaluating selves is very essential 


\section{International Journal of Science and Research (IJSR) \\ ISSN (Online): 2319-7064}

Index Copernicus Value (2015): 78.96 | Impact Factor (2015): 6.391

strategy of self regulation, but majority students do not apply meta-cognitive strategies like self test (e.g. self feedback), and thinking carefully about learning strategies they use. They also get easily distracted from their plans, and don't satisfactorily work on more writing practice tasks as motivational strategy; they do not have short and long term plans to achieve their set goal (expected grade). Compared with the rest items they were asked as part of help seeking strategies, students do not have an experience of sharing their problems of writing with their peers.

- Another main objective of the study was finding out the challenges students and writing skills teachers face. According to the finding obtained both from students and teachers, lack of awareness among students on what strategy to choose and how to use it, lack of interest among students to work cooperatively with mates, lack of more concentrated practice on writing tasks are some of hindering factors. In addition to these, learners' resistance to more writing tasks (to expose them to the skill) given by their teachers, teacher dominated corrective feedback provision to every activity, and lack of sufficient time to teach what strategy students need to use were taken challenges that affect both teachers and students not to practice self regulated learning strategies.

- Creating self regulated learning environments for the complex and diverse range of backgrounds, especially at university setting, skill sets and personalities that many students encompass poses challenges to the instructors. Thus, writing skills instructors were found using explicit corrective feedback, and explicitly explaining strategies called direct instruction, and student centered instructions like group work. But it is found to be very limited (insufficient) strategies, so effective instructional strategies for such reasons and based on different literature are recommended in the next session.

\subsection{Recommendations}

Based on the findings of the study, the researcher has suggested the following recommendations:

- Regarding their use of self regulated learning strategies, the finding indicates that many students do not use their arranged time schedule or plan. According to Elizabeth et'al (2011), planning can help students self-regulate their learning prior to engaging in learning tasks. So, writing skills instructors, the department head and even network mentors should create awareness among the students about making use of a plan to study, and the uses of choosing appropriate tasks in their time of tiredness.

- In addition to this, students should also use self evaluation strategies such as self test and self feedback because "students are more likely to become self-regulated learners when they are able to evaluate their own learning, independent of teacher-issued assessments" (Winne \& Hadwin, 1998, as cited in Elizabeth et'al, 2011, pp.13).

- The study also shows that majority of the students are good at in using self motivation strategies; however, in some extent, it is found that they do not like to take more writing practices tasks, but, as Corno(1993) states it is important to the process of self-regulation because it requires learners to assume control over their learning. Therefore, students should have intrinsic motivation learning without waiting for external incentives.
- Concerning the strategies writing skills instructors use, the finding states that the instructors, to encourage students self regulated learning in the courses, use explicit corrective feedback, direct instruction, and group works; however, according to the reviewed literatures, writing skills instructors should use more strategies like Guided and Independent Practice because independent practice naturally follows guided practice (that means student might practice implementing a specific writing strategy while the teacher carefully observes and offers help when necessary), minimizing explicit corrective feedbacks that means use progress feedback (informing what they did well and what they need to improve as well as steps they can take to improve their work) and use of reflective practice because it may enable teachers to investigate and can better create meaningful learning experiences for their students (Gibson et'al, 2011).

\section{References}

[1] Andreassen, R. \& Braten, I. (2011). Implementation and effects of explicit reading comprehension instruction in fifth-grade classrooms. Learning and Instruction, 21, 520-537.

[2] Baba, H. (2001). Self-access on a Shoestring. Presentation at TESOL Arabia Abu Dhabi Branch Conference, Abu Dhabi Model School, United Arab Emirates.

[3] Barnard,L., Lan,W.Y., To, Y.M., Paton,V.O. \& Lai,S.L. (2009). Measuring self regulation in online and blended learning environment. Internet and Higher Education 12(1), 1-6

[4] Boekaerts, M., \& Cascallar, E. (2006). How far have we moved toward the integration of theory and practice in self-regulation? Educational Psychology Review, 18 (3), 199-210.

[5] Boekaerts, M. \& Corno, L. (2005). Self-regulation in the classroom: A perspective on assessment and intervention. Applied Psychology: An International Review, 54(2), 199-231.

[6] Boekaerts, M. \& Niemivirta, M. (2000). Self-Regulated Learning. Finding a balance between learning goals Ego-Protective goals.

[7] Butler, R. (1998). Determinants of help seeking: Relations between perceived reasons for classroom help-avoidance and help-seeking behaviors in an experimental context. Journal of Educational Psychology, 90, 630-643.

[8] Cleary, T.J., \& Chen, P.P. (2009). Self-regulation, motivation, and math achievement in middle school: variations across grade level and math context. Journal of School Psychology, 47 (5), 291-314.

[9] Corno, L. (1993). The Best-laid plans: Modern conceptions of volition and educational research. Educational Researcher, 22, 14-22.

[10] De Corte, E., Mason, L., Depaepe, F., \& Verschaffel, L. (2011). Self-regulation of mathematical knowledge and skills. In B. J. Zimmerman, \& D. H. Schunk (Eds.), Handbook of self-regulation of learning and performance (pp. 155-172). New York: Routledge.

[11] Elizabeth, D.R., Tadlock,,J. \& Zumbrunn, S. (2011). Encouraging self regulated learning in the class room: A review of the related literature

\section{Volume 6 Issue 1, January 2017




\section{International Journal of Science and Research (IJSR) \\ ISSN (Online): 2319-7064}

Index Copernicus Value (2015): 78.96 | Impact Factor (2015): 6.391

[12] Farahani, M. (2014). From Spoon Feeding to SelfFeeding: Are Iranian EFL Learners Ready to Take Charge of their Own Learning? Electronic Journal of Foreign Language Teaching 2014, Vol. 11, No. 1, pp. 98-115

[13] Fruhmann, K. Nussbaumer, A. \& Albert, D. (n.d) A Psycho-Pedagogical Framework for Self- Regulated Learning in a Responsive Open Learning Environment. Knowledge Management Institute: Graz University of Technology

[14] Gibson, M., Hauf, P., \& Long, B. S. (2011). Reflective practice in service learning: Possibilities and limitations. Education \& Training, 53 (4), 284-296.

[15] Harnishferger, K. K. (1995). The development of cognitive inhibition: Theories, definitions, research. In F. N. Dempster \& C. J. Brainerd (Eds.), Interference and Inhibition in Cognition (pp. 176-206). San Diego: Academic Press.

[16] Harris, K. R., Friedlander, B.D., Saddler, B., Frizzelle, R. \& Graham, S. (2005). Self-monitoring of attention versus self-monitoring of academic performance: Effects among students with ADHD in the general education classroom. Journal of Special Education, 39 (3), 145-156.

[17] Kistner, S., Rakoczy, K., \& Otto, B. (2010). Promotion of self-regulated learning in classrooms: Investigating frequency, quality, and consequences for student performance. Metacognition and Learning, 5 (2), 157171.

[18]Kuhl, J. (1985) Volitional mediators of cognitionbehavior consistency: self-regulatory processes and action versus state orientation. In J. Kuhl and $\mathbf{J}$. Beckman (eds) Action Control: From Cognition to Behavior (pp. 101-128). New York: Springer.

[19]Labuhn, A.S., Zimmerman, B.J., \& Hasselhorn, M. (2010). Enhancing students' self-regulation and mathematics performance: The influence of feedback and self-evaluative standards Metacognition and Learning, 5 (2), 173-194.

[20] Levy, N.R. (1996). Teaching analytical writing: Help for general education middle school teachers. Intervention in School and Clinic, 32(2), 95-103.

[21] Meyer, B., Haywood, N., Sachdev, D., \& Faraday,S. (2008). Independent learning. Literature Review, Nottingham:DCSF

[22] Montalvo, F.T., \& Torres, M.C. (2008). Self-regulated learning: Current and future Directions. Electronic Journal of Research in Educational Psychology, 2(1), 134.

[23] Nunan, D. (1994). Towards autonomous learning: some theoretical, empirical and practical issues. Hong Kong: Hong Kong University Press paper.

[24]Paris, S. G., \& Paris, A. H. (2001). Classroom applications of research on self-regulated learning. Educational Psychologist, 36, 89-91.

[25] Paris, S. G., \& Winograd, P. (1990). How Metacognition can promote academic learning and instruction. In B. J. Jones \& L. Idol (Eds.), Dimensions of thinking and cognitive instruction (pp. 15-51).

[26] Pintrich, P. (2000). Multiple goals, multiple pathways: The role of goal orientation in learning and achievement. Journal of Educational Psychology, 92, 544-555.
[27] Pressley, M., \& Woloshyn, v. (1995). Cognitive strategy instruction that really improves children's academic performance (2nd Ed.). Cambridge, MA: Brookline.

[28] Ryan, A. M., Pintrich, P. R., \& Midgley, C. (2001). Avoiding Seeking help in the classroom: Who and why? Educational Psychology Review, 13, 93-114.

[29] Schraw, G., \& Moshman, D. (1995). Meta-cognitive Theories. Educational Psychology Review, 7, 351-371.

[30] Schunk, D. \& Zimmerman, B. (2007). Influencing children's self-efficacy and self-regulation of reading and writing through modeling. Reading \& Writing Quarterly, 23(1), 7-25.

[31] Schunk, D. H. (2001). Social cognitive theory and selfregulated learning. In Zimmerman, B. J., \& Schunk, D. H. (Eds.) Self-regulated Learning and Academic Achievement: Theoretical Perspectives. Mahwah, NJ. Lawrence Erlbaum Associates.

[32] Stephanie M. and Vic B. (2010). Defining the "Independent Learner" in UK Higher Education: Staff and Students' Understanding of the Concept. International Journal of Teaching and Learning in Higher Education. Vol 24 (20) 209-220.

[33] Stoeger, H., \& Ziegler, A. (2011). Self-regulatory training through elementary-school students' homework completion. In B. J. Zimmerman, \& D. H. Schunk (Eds.), Handbook of self-regulation of learning and performance (pp. 87-101).

[34] Tonks, S. M., \& Taboada, A. (2011). Developing selfregulated readers through instruction for reading engagement. In B. J. Zimmerman, \& D. H. Schunk (Eds.), Handbook of self-regulation of learning and performance (pp. 173-186).

[35] Van den Broek, P., Lorch, R., Linderholm, T., \& Gustafson, M. (2001). The effects of readers' goals on inference generation and memory for texts. Memory \& Cognition, 29, 1081-1087.

[36] Vidal-Arbarca, E., Mana, A., \& Gil, L. (2010). Individual differences for self-regulating task-oriented reading activities. Journal of Educational Psychology, 102(4), 817-826.

[37] Winne, P. H., \& Hadwin, A. F. (1998) Studying as selfregulated learning. In D. J. Hacker \& J. Dunlosky (Eds.), Meta-cognition in educational theory and practice.

[38] Wolters, C. (1998). Self-regulated learning and college students' regulation of motivation. Journal of Educational Psychology, 90, 224-235.

[39] Wolters, C. A. (2003). Regulation of motivation: Evaluating an underemphasized aspect of self-regulated learning. Educational Psychologist, 38, 189-205.

[40] Wood, E.K. and Millichamp, P. (2000). Changing the learning ethos in school. Journal of Inservice Education, 26(3), 499-515.

[41]Zimmerman, B., \& Risemberg, R. (1997). Becoming a self-regulated writer: A social cognitive perspective. Contemporary Educational Psychology, 22, 73-101.

[42]Zimmearman, B. \& Schunk, D. (Eds) (1998). Selfregulated learning:From teaching to self-reflective practice. New York; Guilford Press.

[43]Zimmerman, B. J. (2004). Sociocultural influence and students' development of academic self-regulation: A social-cognitive perspective. In D. M. McInerney \& S. Van Etten (Eds.), Big theories revisted (pp.139-164). 


\section{International Journal of Science and Research (IJSR) \\ ISSN (Online): 2319-7064}

Index Copernicus Value (2015): 78.96 | Impact Factor (2015): 6.391

[44]Zimmerman, B. (2008). Investigating self-regulation and motivation: Historical background, methodological developments, and future prospects. American Educational Research Journal, 45(1), pp. 166-183.

Volume 6 Issue 1, January 2017 www.ijsr.net 